\title{
The oldest brachiopods from the lower Cambrian of South Australia
}

Timothy P. Topper, Lars E. Holmer, Christian B. Skovsted, Glenn A. Brock, Uwe Balthasar, Cecilia M. Larsson, Sandra Pettersson Stolk, and David A.T. Harper

Acta Palaeontologica Polonica 58 (1), 2013: 93-109 doi: http://dx.doi.org/10.4202/app.2011.0146

The morphology and organophosphatic shell structure of the paterinate brachiopod Askepasma is documented using new and previously collected specimens from the lower Cambrian of South Australia. Lack of adequately preserved material has seen the majority of paterinate specimens previously reported from South Australia referred to the genus Askepasma and treated under open nomenclature. Large collections of paterinates from the lower Cambrian Wilkawillina, Ajax, and Wirrapowie limestones in the Arrowie Basin, South Australia have prompted redescription of the type species Askepasma toddense and the erection of a new species, Askepasma saproconcha sp. nov. Askepasma saproconcha sp. nov. currently represents the oldest known brachiopod from the lower Cambrian successions in South Australia with a FAD in pre-trilobitic (Terreneuvian, Cambrian Stage 2, lower Atdabanian) strata in the basal part of the Wilkawillina and Wirrapowie limestones. Askepasma toddense predominantly occurs in Abadiella huoi Zone equivalent strata (Unnamed Cambrian Series 2, Stage 3, middle-upper Atdabanian) in the upper part of the lower Wilkawillina, Wirrapowie, and Ajax limestones. The shell microstructure of Askepasma suggests a proximal stem group position within the Brachiopoda and similarities with tommotiid taxa provides further evidence that the ancestry of crown group brachiopods is firmly entrenched within the Tommotiida.

Key words: Brachiopoda, Tommotiida, Paterinida, Askepasma, microstructure, Flinders Ranges, Arrowie Basin, lower Cambrian, South Australia.

Timothy P. Topper [timothy.topper@ snm.ku.dk], Department of Earth Sciences, Palaeobiology, Uppsala University, Villavägen 16, SE-752 36 Uppsala, Sweden and Geologisk Museum, Statens Naturhistoriske Museum, Øster Voldgade 5-7, DK-1350 København K, Denmark; Lars E. Holmer [1ars.holmer@ pal.uu.se], Cecilia M. Larsson [cecilia.larsson@geo.uu.se], and Sandra Pettersson Stolk [Sandra.Petterson@geo.uu.se], Department of Earth Sciences, Palaeobiology, Uppsala University, Villavägen 16, SE-752 36 Uppsala, Sweden; Christian B. Skovsted [Christian.Skovsted@nrm.se], Department of Palaeozoology, Swedish Museum of Natural History, Box 50007, SE - 10405 Stockholm, Sweden; Glenn A. Brock [glenn.brock@mq.edu.au], 
Department of Biological Sciences, Macquarie University, Sydney, NSW, 2109, Australia; Uwe Balthasar [Uwe.Balthasar@glasglow.ac.uk], School of Geographical and Earth Sciences, Gregory Building, Lilybank Gardens, University of Glasgow, G12 8QQ, UK; David A.T. Harper [Dharper@snm.ku.dk], Geologisk Museum, Statens Naturhistoriske Museum, Øster Voldgade 5-7, DK-1350 København K, Denmark.

This is an open-access article distributed under the terms of the Creative Commons Attribution License (for details please see creativecommons.org), which permits unrestricted use, distribution, and reproduction in any medium, provided the original author and source are credited.

For Full text $(1,379.8 \mathrm{kB})$ 